\title{
PENGEMBANGAN ALAT UKUR EVALUASI DAN PERANCANGAN PRODUK KURSI RODA
}

\author{
Hapsoro Agung Jatmiko dan Rini Dharmastiti* \\ Departemen Teknik Mesin dan Industri, Fakultas Teknik \\ Universitas Gadjah Mada \\ Email: Agungjatmiko911@yahoo.com dan rini@ugm.ac.id*
}

\begin{abstract}
A wheelchair is one of the mobility aids for people with disabilities. Availability of wheelchair type is very decisive for users based on the limitations they have. The problem felt by users in Indonesia today, especially in Yogyakarta, is that users have not got the right kind of wheelchairs with the needs, with certain limitations. This study aims to develop a wheelchair evaluation and to know the user's expectation of the wheelchair design. This study shows that there are problems due to the users not getting a wheelchair that suits their needs. The wheelchair design that the users want are the wheelchair with three wheels and have new feature.
\end{abstract}

Keywords: Factor Analysis; House of Quality; PEQ; Product Design; Wheelchair Evaluation.

\begin{abstract}
ABSTRAK
Kursi roda adalah salah satu alat bantu mobilitas bagi orang yang mempunyai keterbatasan. Ketersediaan jenis kursi roda sangat menentukan bagi pengguna dalam memilih sesuai dengan keterbatasan yang dipunyai. Permasalahan yang dirasakan oleh pengguna di Indonesia saat ini, khususnya di Yogyakarta adalah pengguna belum mendapatkan jenis kursi roda yang tepat dengan kebutuhan, dengan keterbatasan tertentu. Penelitian ini bertujuan mengembangkan metode evaluasi kesesuaian kursi roda dengan penggunanya dan mengetahui ekspektasi pengguna terhadap desain kursi roda yang diinginkan. Penelitian ini menunjukkan bahwa terdapat kekurangan dan permasalahan akibat pengguna tidak mendapat kursi roda yang sesuai dengan kebutuhannya dan mengharuskan adanya pergantian kursi roda yang dimiliki. Desain kursi roda yang diinginkan pengguna adalah kursi roda dengan tiga roda dengan fitur baru pada kursi roda tersebut.
\end{abstract}

Kata Kunci: Desain Produk; Evaluasi kursi roda; Faktor Analisis; House of Quality; PEQ. 


\section{PENGANTAR}

Menurut data Survei Penduduk Antar Sensus (SUPAS) tahun 2015, setidaknya terdapat 7.808.377 Warga Negara Indonesia (WNI) yang mengalami kesulitan dalam berjalan. Data SUPAS 2015 yang berada di Yogyakarta juga menunjukkan bahwa setidaknya terdapat 31.825 orang di Yogyakarta yang mengalami kesulitan jalan. Salah satu alat bantu kesehatan yang dapat membantu meningkatkan mobilitas bagi difabel adalah kursi roda. Menurut Armstrong dkk., (2008), dengan menggunakan kursi roda, kaum difabel akan mendapatkan keuntungan, seperti peningkatan kualitas hidup, tingkat kesehatan, dan kondisi ekonomi. Penggunaan kursi roda yang tepat bagi kaum difabel akan memperbaiki beberapa kondisi kesehatan mereka dan mencegah potensi semakin memburuknya kondisi kesehatan difabel. Selain perbaikan kesehatan, tentu saja adalah peningkatan mobilitas. Kondisi di pasaran, menunjukkan bahwa jenis kursi roda yang tersedia dan dijual di pasaran mempunyai keterbatasan jenis. Menurut Iksal dan Darno (2012), kondisi alat bantu kursi roda yang ada selama ini masih menggunakan konsep "one fits for all", yaitu kursi roda dengan satu jenis, tetapi diperuntukkan kepada semua orang. Hal tersebut dapat menimbulkan masalah karena kebutuhan pengguna kursi roda dapat berbeda satu sama lain, bergantung dari banyak faktor seperti usia dan penyakit yang diderita. Selain itu, saat ini belum ada alat ukur untuk mengevaluasi penggunaan kursi roda yang disesuaikan dengan penggunanya. Salah satu alat ukur performa penggunaan alat kesehatan adalah Prosthetic Evaluation Questionnaire (PEQ). Selain itu, diharapkan juga alat ukur yang terbentuk dapat menangkap keinginan dan sesuai dengan kebutuhan pengguna. Untuk memenuhi produk kursi roda yang sesuai dengan kebutuhan dan keinginan pengguna, maka perlu dipertimbangkan keterbatasan pengguna atau kondisi kesehatan, fisiologi, dan anatomi pengguna.

Steele (1970), menyatakan bahwa evaluasi harus memiliki tujuan yang jelas dan bukan hanya untuk kepentingan pribadi, selain itu juga dapat memberikan kontribusi untuk saat ini dan sebagai acuan masa yang akan datang. Susilawati dan Nilakusmawati (2017) menggunakan faktor analisis untuk mengetahui faktor yang mempengaruhi kualitas dari pelayanan bus umum yang berada di Pulau Bali. Data yang dikumpulkan pada penelitian ini merupakan data primer yang didapatkan melalui proses pengisian kuesioner persepsi kualitas layanan bis umum. Pertanyaan pada kuesioner tersebut berjumlah 25, setelah dilakukan penelitian, dengan pengujian reliabilitas dan validitas. Adapun enam faktor yang terbentuk dalam kuesioner tersebut adalah safety and comfort, responsiveness, capacity, tangibles, safety, dan reliability.

Quality Function Deployment (QFD) adalah sebuah metode yang dikembangkan Yuji Akao yang bertujuan untuk menangkap keinginan konsumen yang kemudian dinyatakan sebagai faktor teknis untuk dikembangkan menjadi sebuah produk. Menurut Zadry bahwa menerapkan metode QFD pada proses perancangan produk kesehatan (stretcher) dengan cara kuesioner untuk menentukan kebutuhan konsumen, setelah itu diberikan pembobotan untuk menentukan kebutuhan utama (Zadry dkk, 2015). Dengan demikian, diperoleh salah satu kebutuhan penting dari stretcher yaitu pemilihan material atau bahan dalam perancangan stretcher. Kursi roda dirancang untuk memiliki banyak nilai kegunaannya (Kumar dkk, 2012). Dalam penelitiannya, mereka melakukan studi pasar terhadap produk-produk kursi roda yang akan menjadi kompetitor. Selain itu, proses pencarian kebutuhan untuk desain kursi roda baru menggunakan metode Etnografi. Dengan mengintegrasikan kedua metode tersebut, maka didapatlah sebuah desain kursi roda yang memberikan kemudahan untuk melakukan kegiatan di rumah seperti berganti pakaian. Penelitian oleh Khan (2015), mengembangkan kursi dengan motor sebagai penggeraknya. Kursi roda yang didesain ini bertenaga baterai dan dapat berbelok ke kanan atau ke kiri melalui tuas pengatur serta dapat melaju dengan kecepatan $6 \mathrm{~km} / \mathrm{jam}$. Produk ini diharapkan dapat dibeli oleh masyarakat dengan ekonomi terbatas karena memiliki harga jual yang murah dan dapat digunakan 
oleh kaum difabel di seluruh India. Behrman (1992) menerapkan metode etnografi untuk mengobservasi pengguna kursi roda dan pengaruh kursi roda yang dimiliki dengan mobilitas yang dapat dilakukan. Metode Etnografi juga dipergunakan oleh Cress et al., (2002) yang melakukan evaluasi dan penilaian terkait performa kursi roda yang dimiliki para pengguna. Proses penilaian dan evaluasi kursi roda dilakukan dengan pengamatan langsung dalam sebuah ruangan yang sudah terkondisikan dengan melakukan beberapa tugas yang sudah ditetapkan sebelumnya.

Penelitian ini bertujuan untuk mengembangkan metode evaluasi kesesuaian kursi roda dengan penggunanya dan mengetahui ekspektasi pengguna terhadap desain kursi roda yang diinginkan, sehingga diperoleh desain baru kursi roda sesuai dengan keinginan dan kebutuhan pengguna.

Penelitian ini dimulai dengan pembuatan kuesioner untuk evaluasi penggunaan kursi roda berdasarkan PEQ. Setelah itu kuesioner tersebut diberikan kepada 44 responden yang juga pengguna kursi roda. Dari data yang diperoleh dari kuesioner tersebut, dilakukan pengujian validitas dan reliabilitas, serta pengelompokan responden. Selain itu, dilakukan analisa faktor untuk melihat faktor-faktor utama yang menjadi kebutuhan responden atau pengguna kursi roda. Pembobotan masing-masing kebutuhan dilakukan dengan metode pairwise comparison, dan setelah itu dibuatlah House of Quality (HOQ). Desain yang diinginkan oleh pengguna kursi roda dibuat berdasarkan kebutuhan yang telah diperoleh tersebut. Sebaran responden yang juga pengguna kursi roda berdasarkan usia, pekerjaan, dan alasan menggunakan kursi roda, dapat dilihat pada Gambar 1. Sebagian besar pengguna kursi roda adalah usia produktif karena mengalami sakit, seperti polio (43\%), penyakit anggota gerak sejak lahir (41\%), dan celebral palsy (16\%).

\section{HASIL DAN PEMBAHASAN}

Pengujian validitas dan reliabilitas dilakukan pada kuisioner dengan 37 pertanyaan. Hasisl uji validitas menunjukkan bahwa lima pertanyaan dinyatakan tidak valid karena
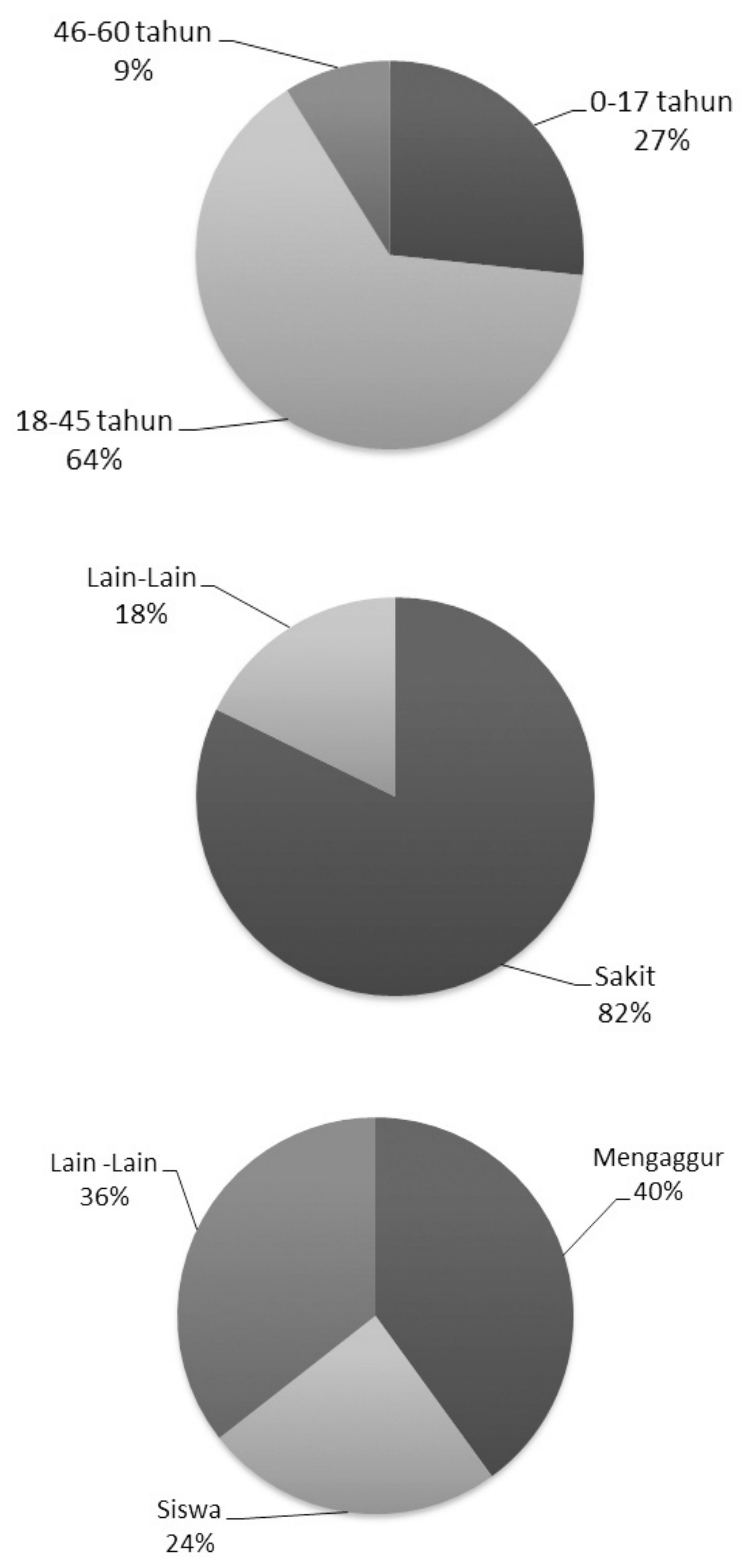

Gambar 1.

Kelompok responden (pengguna kursi roda) berdasarkan usia, pekerjaan, dan alasan menggunakan kursi roda

memiliki nilai $r$ hitung lebih rendah dari nilai $r$ tabel, sementara pada uji reliabilitas, mengacu pada parameter yang ditetapkan Altman (1991), sembilan parameter yang terdapat pada bagian kedua masuk pada kategori biasa, bagus, dan sangat bagus.

Untuk mengetahui faktor yang terbentuk dari data yang sudah diperoleh, maka dilakukan faktorisasi dengan menggunakan metode Eigenvalue. Faktorisasi menentukan faktor- 


\section{HAPSORO AGUNG JATMIKO DAN RINI DHARMASTITI \& PENGEMBANGAN ALAT UKUR EVALUASI DAN PERANCANGAN PRODUK KURSI RODA}

faktor sejenis yang akan menjadi kebutuhan utama, yang kemudian akan digunakan dalam proses selanjutnya yaitu Quality Function
Deployment (QFD). Proses faktorisasi dengan metode Eigenvalue ditunjukkan pada Tabel 1.

Tabel 1.

Hasil Faktorisasi dengan Metode Eigenvalues

\begin{tabular}{|c|c|c|c|c|c|c|c|c|c|}
\hline \multirow{2}{*}{ Component } & \multicolumn{3}{|c|}{ Initial Eigenvalues } & \multicolumn{3}{|c|}{$\begin{array}{c}\text { Extraction Sums of Squared } \\
\text { Loadings }\end{array}$} & \multicolumn{3}{|c|}{$\begin{array}{c}\text { Rotation Sums of Squared } \\
\text { Loadings }\end{array}$} \\
\hline & Total & $\begin{array}{c}\% \text { of } \\
\text { Variance }\end{array}$ & $\begin{array}{c}\text { Cumulative } \\
\%\end{array}$ & Total & $\begin{array}{c}\% \text { of } \\
\text { Variance }\end{array}$ & $\begin{array}{c}\text { Cumulative } \\
\% \\
\end{array}$ & Total & $\begin{array}{c}\% \text { of } \\
\text { Variance }\end{array}$ & $\begin{array}{c}\text { Cumulative } \\
\%\end{array}$ \\
\hline 1 & 8,212 & 48,305 & 48,305 & 8,212 & 48,305 & 48,305 & 3,911 & 23,009 & 23,009 \\
\hline 2 & 1,607 & 9,451 & 57,755 & 1,607 & 9,451 & 57,755 & 3,094 & 18,202 & 41,211 \\
\hline 3 & 1,336 & 7,860 & 65,615 & 1,336 & 7,860 & 65,615 & 2,669 & 15,701 & 56,912 \\
\hline 4 & 1,098 & 6,459 & 72,075 & 1,098 & 6,459 & 72,075 & 2,578 & 15,163 & 72,075 \\
\hline 5 & ,984 & 5,790 & 77,864 & & & & & & \\
\hline 6 & 900 & 5,294 & 83,159 & & & & & & \\
\hline 7 & 649 & 3,815 & 86,974 & & & & & & \\
\hline 8 & ,535 & 3,149 & 90,123 & & & & & & \\
\hline 9 & ,406 & 2,391 & 92,513 & & & & & & \\
\hline 10 & 299 & 1,757 & 94,270 & & & & & & \\
\hline 11 & 270 & 1,585 & 95,855 & & & & & & \\
\hline 12 & 211 & 1,240 & 97,095 & & & & & & \\
\hline 13 & 193 & 1,137 & 98,232 & & & & & & \\
\hline 14 & 106 & 621 & 98,853 & & & & & & \\
\hline 15 & ,091 & ,534 & 99,387 & & & & & & \\
\hline 16 & ,066 & ,389 & 99,776 & & & & & & \\
\hline 17 & ,038 & ,224 & 100,000 & & & & & & \\
\hline
\end{tabular}

Berdasarkan pada proses faktorisasi kan tabel kebutuhan berdasarkan komponen diketahui bahwa terbentuk 4 faktor yang yang terbentuk. memiliki nilai Eigenvalue $\geq 1$. Tabel 2 menunjuk-

Tabel 2.

Kebutuhan Berdasarkan Komponen Pembentuk dan Respon Teknis

\begin{tabular}{lll}
\hline No Kebutuhan yang Terbentuk & \\
\hline $1 \quad$ Faktor Utilitas & Ketebalan Bantalan Duduk \\
& Dimensi Kursi Roda \\
& Komponen Pendukung Kursi Roda \\
& Material Bantalan Duduk \\
& Berat Kursi Roda \\
& Jumlah Roda Kursi Roda \\
& Ketersedian Slot untuk Part Tambahan \\
& Kecepatan Proses Pemasangan (Assembly) \\
& Jumlah Part \\
\hline $2 \quad$ Faktor Estetika \& Keamanan & Dimensi Kursi Roda \\
& Jumlah Part \\
& Ketersedian Slot untuk Part Tambahan \\
& Material Kursi Roda \\
& Komponen Pendukung \\
& Material Bantalan Duduk \\
& Ketebalan Bantalan Duduk \\
& Jumlah Roda
\end{tabular}




\begin{tabular}{lll}
\hline No & Kebutuhan yang Terbentuk & \\
\hline 3 & Faktor Fleksibilitas & Berat Kursi Roda \\
& & Dimensi Kursi Roda \\
& Kecepatan Proses Pemasangan (Assembly) \\
& Ketersedian Slot untuk Part Tambahan \\
& Jumlah Part \\
\hline \multirow{2}{*}{ Faktor Sosial \& Psikologi } & Komponen Pendukung \\
& Berat Kursi Roda \\
& Material Kursi Roda \\
& Kecepatan Proses Pemasangan (Assembly) \\
& Jumlah Part \\
\hline
\end{tabular}

Keempat faktor yang terbentuk, kemudian diberi penamaan berdasarkan kesamaan pertanyaan yang terdapat pada masing-

masing faktor. Gambar 2 menunjukkan HOQ yang diperoleh berdasarkan kuesioner yang diberikan kepada pengguna kursi roda.

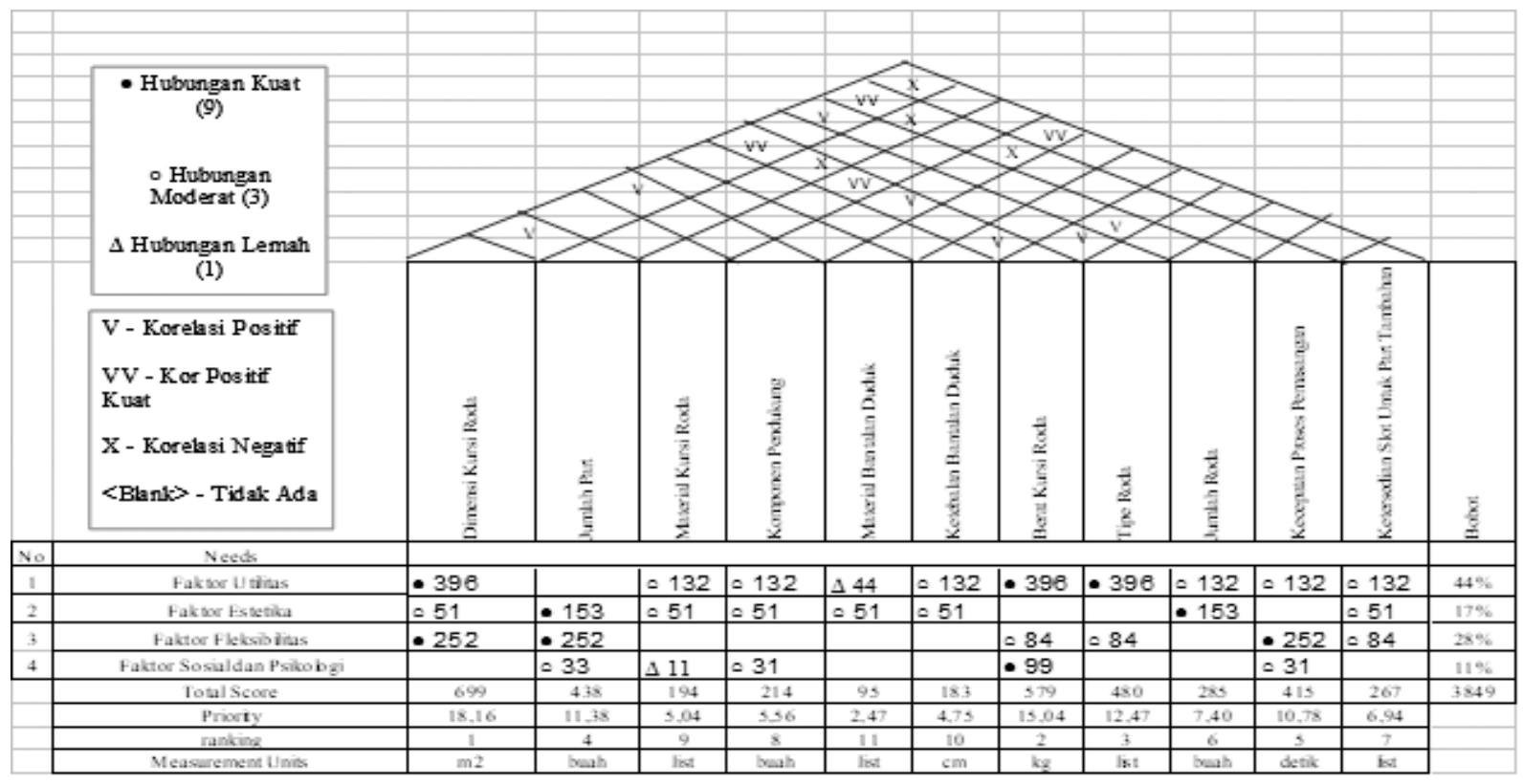

Gambar 2.

House of Quality

Berdasarkan Tabel 2 dan Gambar akhir desain kursi roda seperti terlihat 2 tersebut, maka dihasilkan spesifikasi pada Tabel3.

Tabel 3.

Spesifikasi Final Desain Kursi Roda

\begin{tabular}{llll}
\hline No & \multicolumn{1}{c}{ Respon Teknis } & Satuan & \multicolumn{1}{c}{ Spesifikasi Akhir } \\
\hline 1 & Dimensi Kursi Roda & & \\
a & Ukuran dudukan kursi roda & $\mathrm{cm}$ & $40 \mathrm{~cm} \mathrm{X} \mathrm{40} \mathrm{cm}$ \\
b & Ukuran sandaran kursi roda & & $40 \mathrm{~cm} \mathrm{X} \mathrm{40} \mathrm{cm}$ \\
c & Diameter roda & Buah & $86 \mathrm{~cm}$ \\
2 & Jumlah part & List & Aluminium dan Material Komposit \\
3 & Material kursi roda & &
\end{tabular}


HAPSORO AGUNG JATMIKO DAN RINI DHARMASTITI PENGEMBANGAN ALAT UKUR EVALUASI DAN PERANCANGAN PRODUK KURSI RODA

\begin{tabular}{|c|c|c|c|}
\hline No & Respon Teknis & Satuan & Spesifikasi Akhir \\
\hline 4 & Komponen pendukung & Buah & 3 buah \\
\hline 5 & Isian bantalan duduk & List & Udara \\
\hline 6 & Ketebalan bantalan duduk & $\mathrm{Cm}$ & $\pm 6-5 \mathrm{~cm}$ \\
\hline 7 & Berat kursi roda & $\mathrm{Kg}$ & $\pm 15 \mathrm{~kg}$ \\
\hline 8 & Tipe isian roda & List & Pneumatik (Air Filled Tire) \\
\hline 9 & Jumlah roda & Buah & 3 buah \\
\hline 10 & Kecepatan proses pemasangan & Detik & 900 detik \\
\hline 11 & Ketersediaan slot untuk part tambahan & List & Ada \\
\hline
\end{tabular}

Desain yang diinginkan ditunjukkan pada Gambar 3.
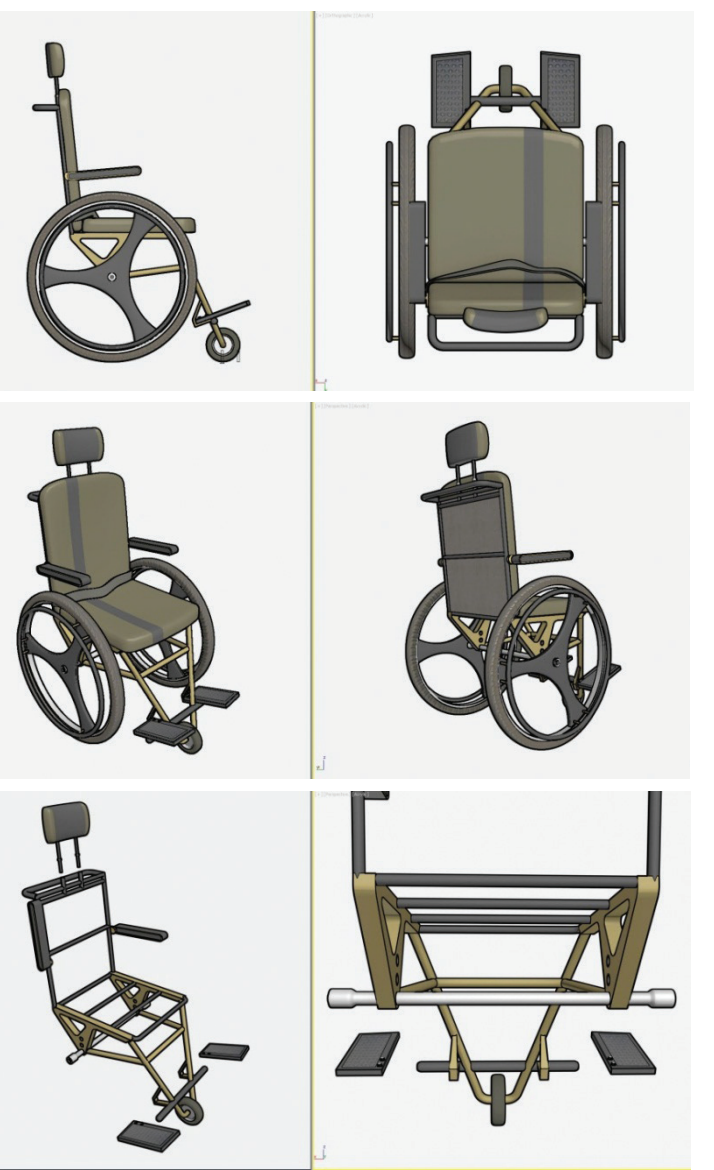

Gambar 3.

Desain Kursi Roda Berdasarkan Spesifikasi Akhir

Proses selanjutnya adalah mendapatkan masukkan dari para pengguna tentang desain kursi roda tersebut. Hasil dari masukan pengguna adalah sebagai berikut:

1. Rem tangan disediakan pada proses gambar selanjutnya.
2. Penghitungan matematis dilakukan untuk mencegah potensi terbalik ke belakang.

3. Perbaikan pada bagian sandaran kaki.

4. Sandaran kepala pada kursi roda ini sifatnya knockdown atau dapat dibongkar pasang.

5. Desain kursi roda dapat dilipat sesuai dengan apa yang diinginkan oleh responden.

Berdasarkan pada poin perbaikan tersebut, didapatkan desain final yang terdapat pada Gambar 4.

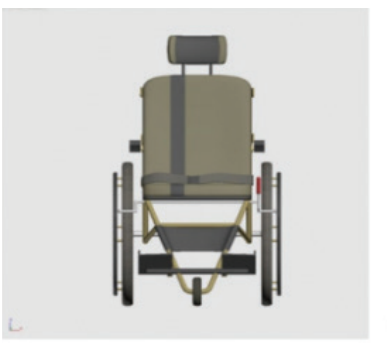

Tampak Depan

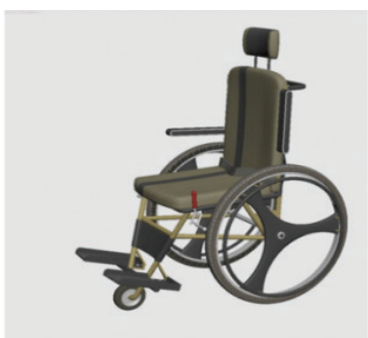

Posisi Pakai

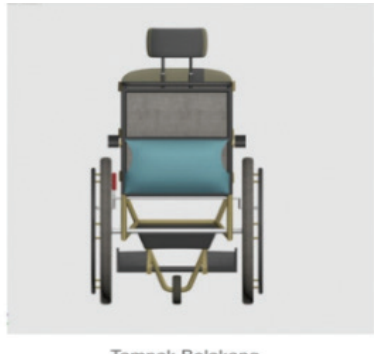

Tampak Belakang

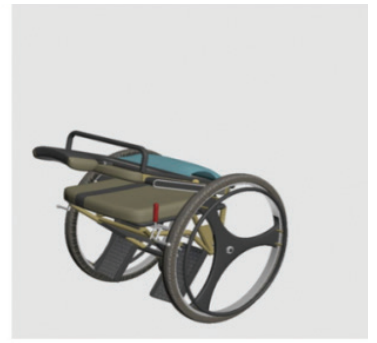

Posisi Lipat
Gambar 3.

Desain Final Sesuai Dengan Masukan Pengguna

\section{SIMPULAN}

Kuisioner yang dihasilkan untuk mengevaluasi kursi roda berdasarkan pengguna adalah valid dan reliabel, dan dapat digunakan untuk melihat keinginan dan 
kebutuhan pengguna. Dari hasil kuesioner itu dapat diperoleh kebutuhan desain kursi roda yang diinginkan yaitu kursi roda dengan roda berjumlah tiga dan terdapat beberapa fitur tambahan.

\section{DAFTAR PUSTAKA}

Altman, D.G., 1991, Practical Statistics for Medical Research, Chapman \& Hall.

Armstrong, W., Borg, J., Krizack, M., Lindsley, A., Mines, K., Pearlman, J., Reisinger, K., Sheldon, S., 2008, Guidelines on the Provision of Manual Wheelchairs in Less Resourced Settings, World Health Organization Press.

Behrman, A., 1992, Factors in Functional Assesment, JRRD Clinical Supplement : Choosing a Wheelchair System, Vol. 2.

Cress, M., E., Kinne, S., Patrick, D., L., Maher, E., 2002, Physical Functional Performance in Persons Using a Manual Wheelchair, Journal of Orthopaedic \& Sports Physical Therapy, Vol. 32, Number 3.

Iksal dan Darno, 2012, Perancangan dan Implementasi Kursi Roda Elektrik Ekonomis Sebagai Sarana Rehabilitasi Medik, Prosiding SNaPP2012 : Sains, Teknologi dan Kesehatan.

Jansen, T.W.J., van Oers, C.A.J.M., Veeger, H.E.J., Hollander, A.P., van der Woude, L.H.V., Rozendal, R.H., 1994, Relationship between Physical
Strain during Standardised ADL Tasks and Physical Capacity in Men with Spinal Cord Injuries, Paraplegia, Vol. 32, pp. 844-859.

Khan, I. A., 2015, Motorized Wheel Chair for Physically Challenged Person.

Kumar, M. R., Lohit, H. S., Mishra, R. M., Ahamed, B., 2012, Design of Multipurpose Wheel Chair for Physically Challenged and Elder People.

Saaty, T.L., 1980, The Analytical Hierarchy Process, McGraw-Hill Inc, United States of America.

Steele, S., M., 1970, Program Evaluation A Broader Definition, Journal of Extension.

Sugiyono, 2010, Statistika Untuk Penelitian, Alfabeta, Bandung.

Susilawati,M.,\&Nilakusmawati,D.P.E.,2017, Study on the Factors Affecting the Quality of Public Bus Transportation Service in Bali Province Using Factor Analysis, International Conference on Mathematics, Education, Theory and Application.

Zadry, H. R., Rahmayanti, D., Susanti, L., Fatrias, D., 2015, Identification of Design Requirements for Ergonomic Long Spinal Board Using Quality Function Deployment (QFD), $6^{\text {th }}$ International Conference on Applied Human Factors and Ergonomics and the Affiliated Conferences, pp. 4673-4680. 